\title{
VALIDITY AND RELIABILITY OF THE SCREENING TEST FOR ALZHEIMER'S DISEASE WITH PROVERBS (STADP) FOR THE ELDERLY
}

\author{
Mauricéa Tabosa Ferreira Santos ${ }^{7}$ Everton Botelho Sougey ${ }^{2}$, João Carlos Alchieri ${ }^{3}$
}

\begin{abstract}
The prevalence Alzheimer's disease with age compromises memory, language, executive functions, constructive praxis and abstraction, requiring early evaluation with standardized tests. Objective: To validate the Screening Test for Alzheimer's Disease with Proverbs (STADP), elaborated using pieces from the proverb memory game. Method: The test contains three stages (A: short-term memory, B: executive functions and language and C: episodic memory). The sample consisted of 91 elderly individuals with minimum age of 60 years and one year of schooling, CDR of one or zero, cared for at specialized services of UFPE, HGA and private institutions. Sociodemographic data, habits and health perception were assessed. Among the tests used were MMSE (convergent validity) and GDS (discriminating). Results: A good correlation with standardized test was found, acceptable internal consistency (0.71), cutoff point for schooling of 6.49 (low) (80\% and $77.8 \%$ ) and 8.66 (high) ( $84.6 \%$ and $86.1 \%)$; Kappa coefficient of $1(\mathrm{p}=0.000)$ inter-rater consistency. Conclusion: STADP is a valid test for screening Alzheimer's disease.
\end{abstract}

KEY WORDS: Alzheimer's disease, proverbs, language, test validity.

\begin{abstract}
Validade e confiabilidade do teste de rastreio de Doença de Alzheimer com provérbios (TRDAP) para idosos
Resumo - A prevalência da doença de Alzheimer com o envelhecimento, que compromete memória, linguagem, funções executivas, praxia construtiva e abstração, necessita avaliação precoce com testes padronizados. Objetivo: Validação do Teste de Rastreio de Doença de Alzheimer com Provérbios (TRDAP), elaborado com pedras do jogo de memória de provérbios. Método: $O$ teste contém três etapas (A: memória curto-prazo, B: funções executivas e linguagem e C: memória episódica). A amostra tinha 91 idosos com mínimos de 60 anos e de um ano de escolaridade, CDR (um ou zero), de serviços especializados da UFPE, HGA e particular. Avaliaram-se dados sociodemográficos, hábitos e percepção de saúde. Dentre os testes utilizados - MEEM (validade convergente), EDG (discriminante). Resultados: Apontaram para boa correlação com testes padronizados, consistência interna aceitável (0,71); ponto de corte por escolaridade foi 6,49 ( $80 \%$ e $77,8 \%$ ) baixa, e alta 8,66 (84,6\% e 86,1\%); coeficiente Kappa igual a $1(\mathrm{p}=0,000)$ inter-avaliadores. Conclusão: O TRDAP mostra-se válido para rastrear doença de Alzheimer.
\end{abstract}

PALAVRAS-CHAVE: doença de Alzheimer, provérbios, memória, linguagem, validade de testes.

With aging, the presence of chronic incapacitating diseases, such as Alzheimer's disease (AD), compromises the independence and autonomy of individual ${ }^{1-5}$. Studies on the initial phase of the disease point to deficits in episodic declarative memory and in executive functions, with an impact on daily activities ${ }^{6-8}$, causing family distress and increasing the likelihood of institutionalization ${ }^{9,10}$, reinforced by language, comprehension and interpretation difficulties $^{11,12}$. Early diagnosis is a clinical priority aimed at preventive multidisciplinary interventions with appropriate measuring instruments for the sociocultural context. There are several instruments, but few have been

Center for Health Sciences of the Universidade Federal do Rio Grande do Norte, Natal, Brazil and Universidade Federal de Pernambuco, Recife PE, Brazil (UFRN and UFPE): 'Occupational therapist, gerontologist and doctoral student in the Postgraduate Program of Health Sciences at UFRN; ${ }^{2}$ Associate Professor, PhD, Department of Neuropsychiatry of UFPE; ${ }^{3}$ Psychologist, Doctor of Psychology and Adjunct Professor in the Department of Psychology at UFRN.

Received 8 June 2009. Accepted 24 July 2009.

Dr. João Carlos Alchieri - Universidade Federal do Rio Grande do Norte / Campus Universitário - Caixa Postal: 1622 - $59078-970$ Natal RN - Brasil. E-mail: jcalchieri@gmail.com e mauricea.to@gmail.com; Home page: www.alchieri.pro.br 
psychometrically defined, standardized and validated for our environment ${ }^{13}$, and mainly in relation to accuracy and assessment time ${ }^{3}$, avoiding errors caused by tiredness and lack of motivation/attention ${ }^{14}$.

The use of proverbs to evaluate concrete and abstract thinking about diseases dates from the $1950 \mathrm{~s}^{15}$, and in $A D$ showed compromise in aspects related to their abstract interpretation ${ }^{3,16}$. Lezak ${ }^{17}$ suggested the use of proverbs associated to the Mini-Mental State Examination (MMSE) ${ }^{18}$ to improve accuracy. The interest in proverbs emerged from clinical observation and interpersonal contact, in the motivation of the elderly to evoke them and transmit them to younger individuals.

This study sought to elaborate an instrument, entitled Screening Test for Alzheimer's Disease with Proverbs $(S T A D P)^{19,20}$, with the ludic and cultural characteristics of the respondents. The STADP consists of six pairs of wooden pieces from the Proverb Memory Game, with legible writing, and six proverbs divided into two parts, at the start and at the end. There are three stages $(A, B, C)$. Stage " $A$ " consists of matching and memorizing the first three proverbs, reading them out loud and then placing the wooden pieces face down; "B" involves matching the other three and the consequent interpretation, read by the examiner, who records the respondent's comments; and " $C$ " the recall of the first three. Total score is 15 points, subdivided into three: (A) 6 points for short-term memory with three consecutive attempts and the possibility of learning; (B) 3 points for executive functions - abstraction/language-syntax; and (C) 6 points for verbal episodic memory. The final result is the sum of the three scores. The respondent is then asked to recognize the proverbs (stage A) among other non-used ones. A preliminary version ${ }^{20,21}$ showed a significant relationship between scores using standardized instruments and more current instruments suitable for the Brazilian reality.

The latter were the basis of the present investigation, aimed at validating the convergent and discriminating construct and determining the reliability of STADP in a sample of elderly individuals.

\section{METHOD}

A total of 92 elderly persons, aged 60 years or older with minimum schooling of one year, took part in the study. Of these, 28 had AD and 63 were controls, assessed by geriatrists and neurologists at specialized centers, the UNATi program at UFPE, the Elderly Care Program of the HGA and at private clinics. The inclusion criteria were $C D R$ of zero or one, meeting the criteria of the Diagnostic and Statistical Manual of Mental Disorders (DSM IV), minimum schooling of one year, not exhibiting visual and auditory deficits or pathologies that compromise the performance of data collection procedures and understanding of the instructions. The exclusion criteria adopted were: moderate depression
(Geriatric Depression Scale $>10$ ), and the non-acceptance of continuity by the elderly subjects. Data collection took place between July 2007 and December 2008 in a quiet and comfortable setting. Trained academics applied the protocols, obtaining the scores and data from the sociodemographic interview, health perception, healthy habits, the Screening Test for Alzheimer's Disease with Proverbs (STADP); the Mini-Mental State Examination (MMSE) - overall assessment of cognition; the Rey Semicomplex Figure - Neuropsi (RN) - visual memory and constructive skills; Word list (WL) - short-term, episodic and recognition memories; Spontaneous Clock Drawing Test (CDT) - executive functions; Digit Span (DS) - short-term memory and executive functions; Geriatric Depression Scale (GDS) - suspected depression; Katz Index (ADL) - degree of functional dependence and Semantic Verbal Fluency (SVF) - language and executive functions. However, the MMSE was used to investigate the validity of the convergent construct with a cutoff point for schooling ${ }^{18,22}$, ( 18 for $1-7$ years and 26 for $\geq 8$ years) and the discriminating construct was the GDS ${ }^{23}$ (reduced version - 15 points), both cited in the literature as being reliable ${ }^{24,25}$. The retest occurred three months later, as well as orientation from a specialist and as retribution to the participants, they were offered a memory workshop. The study was approved by the Research Ethics Committee of UFPE on May 22, 2007 (protocol number 072/07).

The instruments used from the SPSS 15.0 statistical package were: Pearson's correlation test for statistical significance; the Student's t-test - equality of means; Cronbach's Alpha - analysis of the internal consistency of the STADP; the chi-squared test - association between diagnosis of $A D$ and screening using STADP and MMSE, taking schooling into account. Furthermore, the ROC curve was used to attribute the cutoff point with the best sensitivity and specificity and the Kappa test for inter-examiner analysis.

\section{RESULTS}

A total of 91 seniors were assessed, after one was excluded for scoring higher than 10 points on the GDS. The sample profile was analyzed with respect to sociodemographic data, health perception and healthy habits, and it was found that $71 \%$ were women; age varied between 60 and 90 years (39.6\% between $60-69$ and $60.4 \% \geq 70$ ); schooling: $31.9 \%$ ( $1-4$ years), $27.5 \%$ ( $5-7$ years), $20.9 \%$ (8-11 years) and $19.8 \%$ ( $\geq 12$ years). Around $50 \%$ of the participants were married or living with a common-law spouse and had income of more than three minimum monthly family wages (1 minimum monthly income $\approx$ US\$230.00). In regard to health, only $39.6 \%$ of the elderly reported having good health, which coincided with the percentage who took part in social activities. The comorbidities found were classified into: no disease $(5 \%)$, one disease $(29.6 \%)$, two $(28.5 \%)$, three or more $(31.8 \%)$ and no response $(6.1 \%)$, showing greater percentage for one or more diseases, in agreement with the literature ${ }^{26,27}$. Physical activity was re- 
Table 1. Cognitive and mood performance of the sample in the STADP, MMSE and GDS tests.

\begin{tabular}{|c|c|c|c|c|c|c|c|c|c|c|c|}
\hline & & \multirow[b]{2}{*}{$\mathrm{n}$} & \multicolumn{3}{|c|}{ STADP } & \multicolumn{3}{|c|}{ MMSE } & \multicolumn{3}{|c|}{ GDS } \\
\hline & & & Mean & SD & Sig. & Mean & SD & Sig. & Mean & SD & Sig. \\
\hline \multirow[t]{2}{*}{ Sex } & Male & 26 & 7.72 & 4.54 & 0.207 & 24.08 & 4.12 & 0.321 & 3.15 & 2.22 & 0.577 \\
\hline & Female & 65 & 8.93 & 3.95 & & 25.00 & 3.94 & & 3.49 & 2.74 & \\
\hline \multirow[t]{6}{*}{ Age range } & $60-64$ & 20 & 11.21 & 3.61 & 0.000 & 26.95 & 3.33 & 0.000 & 2.80 & 1.76 & 0.770 \\
\hline & $65-69$ & 16 & 9.12 & 4.08 & & 25.50 & 3.58 & & 3.25 & 2.62 & \\
\hline & 70-74 & 25 & 9.24 & 3.73 & & 25.40 & 3.17 & & 3.72 & 3.16 & \\
\hline & 75-79 & 13 & 4.72 & 3.80 & & 22.23 & 4.71 & & 3.92 & 2.96 & \\
\hline & $80-84$ & 11 & 8.30 & 2.65 & & 23.64 & 3.38 & & 3.00 & 2.45 & \\
\hline & $\geq 85$ & 6 & 4.61 & 2.10 & & 20.00 & 3.41 & & 4.00 & 2.19 & \\
\hline \multirow[t]{5}{*}{ Schooling } & $1-4$ & 29 & 6.38 & 3.54 & 0.002 & 22.76 & 4.04 & 0.007 & 4.41 & 2.88 & 0.006 \\
\hline & $5-7$ & 25 & 9.60 & 3.87 & & 25.88 & 2.77 & & 3.00 & 2.10 & \\
\hline & $8-11$ & 19 & 8.82 & 4.43 & & 24.89 & 4.47 & & 3.84 & 2.85 & \\
\hline & $\geq 12$ & 18 & 10.50 & 3.79 & & 26.17 & 3.80 & & 1.83 & 1.54 & \\
\hline & Total & 91 & 8.59 & 4.14 & - & 24.74 & 3.99 & - & 3.40 & 2.60 & - \\
\hline
\end{tabular}

STADP: Screening Test for Alzheimer's Disease with Proverbs; MMSE: Mini-Mental State Examination; GDS: Geriatric Depression Scale.

Table 2. Cognitive performance of the sample in the subtests (stages A.B.C) STADP.

\begin{tabular}{|c|c|c|c|c|c|c|c|c|c|c|c|}
\hline & & \multirow[b]{2}{*}{$\mathrm{n}$} & \multicolumn{3}{|c|}{ STM } & \multicolumn{3}{|c|}{$\mathrm{EF}, \mathrm{L}-\mathrm{STADP}$} & \multicolumn{3}{|c|}{ EM-STADP } \\
\hline & & & Mean & SD & Sig. & Mean & SD & Sig. & Mean & SD & Sig. \\
\hline \multirow[t]{2}{*}{ Sex } & Male & 26 & 3.99 & 1.62 & 0.049 & 1.35 & 1.13 & 0.629 & 2.42 & 2.35 & 0.511 \\
\hline & Female & 65 & 4.66 & 1.38 & & 1.48 & 1.17 & & 2.78 & 2.36 & \\
\hline \multirow[t]{6}{*}{ Age range } & $60-64$ & 20 & 4.96 & 1.35 & 0.002 & 1.95 & 1.09 & 0.111 & 4.30 & 1.92 & 0.000 \\
\hline & $65-69$ & 16 & 4.87 & 1.43 & & 1.31 & 1.19 & & 2.94 & 2.35 & \\
\hline & 70-74 & 25 & 4.72 & 1.37 & & 1.40 & 1.23 & & 3.12 & 2.32 & \\
\hline & 75-79 & 13 & 3.18 & 1.64 & & 0.77 & 1.01 & & 0.77 & 1.59 & \\
\hline & $80-84$ & 11 & 4.57 & 0.86 & & 1.64 & 0.92 & & 2.09 & 1.81 & \\
\hline & $\geq 85$ & 6 & 3.27 & 1.14 & & 1.33 & 1.21 & & 0.00 & 0.00 & \\
\hline \multirow[t]{5}{*}{ Schooling } & $1-4$ & 29 & 3.75 & 1.66 & 0.005 & 0.86 & 0.99 & 0.000 & 1.76 & 2.06 & 0.079 \\
\hline & $5-7$ & 25 & 4.88 & 1.15 & & 1.40 & 1.08 & & 3.28 & 2.37 & \\
\hline & $8-11$ & 19 & 4.45 & 1.59 & & 1.53 & 1.17 & & 2.89 & 2.45 & \\
\hline & $\geq 12$ & 18 & 5.06 & 0.98 & & 2.33 & 0.97 & & 3.11 & 2.39 & \\
\hline & Total & 91 & 4.47 & 1.47 & - & 1.44 & 1.16 & - & 2.68 & 2.35 & - \\
\hline
\end{tabular}

STADP: Screening Test for Alzheimer's Disease with Proverbs; STM: Short-term Memory (stage A); EF,L: Executive Functions and language (stage B); EM: Episodic Memory (stage C).

ported by $60.4 \%$, reading by $56 \%$ and writing by $34.1 \%$ of the respondents, showing that many remained active despite the difficulties observed. Memory problems were cited by $80.2 \%$, but only $26.4 \%$ needed help in daily activities, coinciding with the elderly with AD.

The elderly expressed concern about developing dementia and these individuals were referred to memory workshops, courses at the UNATi and annual health examinations. The total scores on STADP, MMSE and GDS were analyzed in terms of sex, age and schooling (Table 1). The MMSE was used to evaluate convergent validity and GDS for discriminating validity.

Mean performance and the standard deviation of points on the STADP was $8.59 \pm 4.14$, on MMSE $24.74 \pm 3.99$ and on GDS 3.40 \pm 2.60 . There was no significant difference with respect to sex in the STADP, MMSE and GDS results. The results point to the impact of schooling on STADP $(p=0.002)$, on MMSE ( $p=0.007)$ and on GDS ( $p=0.006)$. Age obtained an equal $p=0.000$ in both STADP and MMSE, showing a discrepancy in the 60-64 age range compared to 85 years and older, corroborating other studies ${ }^{12,17,29}$, whereas in GDS there was no significance $(p=0.770)$. However, the 75-90 year range showed lower values on STADP and MMSE compared to the 80-84 year range, as did the schooling range of 8-11 years compared to the 5-7 year range, where the largest number of individuals with $A D$ is concentrated.

The results of the STADP stages were also analyzed by 
Table 3. Pearson's correlation between the STADP stages and some MMSE categories.

\begin{tabular}{|c|c|c|c|c|c|c|c|c|c|}
\hline & & $\begin{array}{l}\text { STADP-STM } \\
\text { Maximum }=6\end{array}$ & $\begin{array}{l}\text { MMSE-STM } \\
\text { Maximum }=3\end{array}$ & $\begin{array}{c}\text { STADP-EF and L } \\
\text { Maximum }=3\end{array}$ & $\begin{array}{l}\text { MMSE-EF and L } \\
\text { Maximum=14 }\end{array}$ & $\begin{array}{c}\text { STADP-EM } \\
\text { Maximum=6 }\end{array}$ & $\begin{array}{c}\text { MMSE-EM } \\
\text { Maximum=3 }\end{array}$ & $\begin{array}{l}\text { STADP -Total } \\
\text { Maximum=15 }\end{array}$ & $\begin{array}{l}\text { MMSE -Total } \\
\text { Maximum }=30\end{array}$ \\
\hline STADP-STM & Pearson's & & & & & & & & \\
\hline \multirow[t]{2}{*}{ Maximum=6 } & correlation & 1 & .013 & $.610(* \star)$ & $.644(* *)$ & $.618(* *)$ & $.439(* \star)$ & $.879(* *)$ & $.711(* *)$ \\
\hline & Sig. & & .904 & .000 & .000 & .000 & .000 & .000 & .000 \\
\hline MMSE-STM & Pearson's & & & & & & & & \\
\hline \multirow[t]{2}{*}{ Maximum=3 } & correlation & & 1 & -.019 & .039 & .104 & .075 & .058 & $.291(* *)$ \\
\hline & Sig. & & & .860 & .712 & .327 & .481 & .582 & .005 \\
\hline \multicolumn{10}{|c|}{ STADP-EF and LPearson's } \\
\hline \multirow[t]{2}{*}{ Maximum=3 } & correlation & & & 1 & $.412(* *)$ & $.322\left(^{* *}\right)$ & $.315(* *)$ & $.673(* *)$ & $\left..4422^{(* *}\right)$ \\
\hline & Sig. & & & & .000 & .002 & .002 & .000 & .000 \\
\hline \multicolumn{10}{|c|}{ MMSE-EF and LPearson's } \\
\hline \multirow[t]{2}{*}{ Maximum=14 } & correlation & & & & 1 & $.415(* *)$ & $.335(* *)$ & $.580(* *)$ & $.736(* *)$ \\
\hline & Sig. & & & & & .000 & .001 & .000 & .000 \\
\hline STADP-EM & Pearson's & & & & & & & & \\
\hline \multirow[t]{2}{*}{ Maximum=6 } & correlation & & & & & 1 & $.614(* *)$ & $.878(* *)$ & $.6699^{(* *}$ \\
\hline & Sig. & & & & & & .000 & .000 & .000 \\
\hline MMSE-EM & Pearson's & & & & & & & & \\
\hline \multirow[t]{2}{*}{ Maximum=3 } & correlation & & & & & & 1 & $.594(* *)$ & $.660\left(^{* *}\right)$ \\
\hline & Sig. & & & & & & & .000 & .000 \\
\hline STADP-Total & Pearson's & & & & & & & & \\
\hline \multirow[t]{2}{*}{ Maximum=15 } & correlation & & & & & & & 1 & $.757(* *)$ \\
\hline & Sig. & & & & & & & & .000 \\
\hline MMSE-Total & Pearson's & & & & & & & & \\
\hline \multirow[t]{3}{*}{ Maximum $=30$} & correlation & & & & & & & & 1 \\
\hline & Sig. & & & & & & & & \\
\hline & $N$ & & & & & & & & 91 \\
\hline
\end{tabular}

STADP: Screening Test for Alzheimer's Disease with Proverbs; MMSE: Mini-Mental State Examination; STM: Short-term Memory; EF: Executive functions; L: Language; EM: Episodic Memory; Maximum: maximum or total scores of each stage.

age and schooling (Table 2), where the effect of age, comparing the extremes, showed poorer performance in the older seniors, but the interference of the presence of $A D$ was greater in all the stages, regardless of age, corroborating Carchat ${ }^{6}$. When episodic and short-term memory were analyzed, statistical significance was found for age, a finding not observed in executive and language functions $(p=0.111)$. However, in terms of schooling, these last two underwent the most interference $(p=0.000)$, in contrast to the findings of Campanha et al. ${ }^{16}$, who found no relationship between schooling and metalinguistic tasks, in interpreting popular proverbs. Short-term memory on STADP was related to schooling $(p=0.005)$, a result not found with episodic memory, which only exhibited a tendency $(p=0.079)$. The $8-11$ year schooling range obtained lower memory scores (Stages $A$ and $C$ ), possibly because it contains more elderly with $A D$, whose memories are significantly more affected by $A D$, confirming data in the international literature.

The convergent validity of STADP was obtained with MMSE, the instrument used in studies screening overall cognition that considers seven categories to assess the following specific cognitive functions: orientation for time (5 points), orientation for place (5 points), registration of 3 words ( 3 points), attention/calculation ( 5 points), recall of 3 words ( 3 points), language (8 points) and visual constructive capacity $(1 \text { point })^{22}$. The three stages $(A, B, C)$ of STADP were compared with the MMSE categories, except for space-temporal orientation, an aspect not evaluated by STADP. In stage A, short-term memory was compared with the registration of 3 words on MMSE; in stage $B$, the executive and language functions with attention/ calculation, visual constructive capacity and language on MMSE; in stage C, episodic memory with the recall of three words on MMSE. The results point to the convergent validity of STADP with MMSE (Table 3), and significant correlation in executive functions and language $(r=0.41$; $p=0.000)$ and episodic memory $(r=0.61 ; p=0.000)$, showing that they exhibit aspects of a same construct. Shortterm memory on STADP showed no relationship ( $r=0.13$; $\mathrm{p}=0.904$ ) with short-term memory on MMSE. It was observed that the tasks used in the two instruments are dis- 
Table 4. Agreement between STADP screening and the other assessments (Medical and MMSE screening).

\begin{tabular}{|c|c|c|c|c|c|c|c|}
\hline & & \multicolumn{3}{|c|}{ MMSE screening } & \multicolumn{3}{|c|}{ Medical diagnosis } \\
\hline & & Control & $A D$ & Total & Control & $A D$ & Total \\
\hline \multirow[t]{3}{*}{ STADP screening } & No screening & 40 & 6 & 46 & 43 & 3 & 46 \\
\hline & Screening & 28 & 17 & 45 & 20 & 25 & 45 \\
\hline & Total & 68 & 23 & 91 & 63 & 28 & 91 \\
\hline
\end{tabular}

MMSE: Mini-Mental State Examination; AD: Alzheimer's Disease; STADP: Screening Test for Alzheimer's Disease with Proverbs.

tinct in short-term memory. STADP showed greater complexity than MMSE, denominated "registration" task on the latter instrument ${ }^{22}$, possibly being the cause of the non-correlation.

The findings corroborate those observed in a metaanalysis study ${ }^{29}$, using 47 articles with more than nine thousand controls and over one thousand patients with pre-clinical AD, analyzing the size of the effect on cognitive skills after three years. It was observed that episodic memory and executive functions were the most affected, in addition to those not contained on STADP. This same study reports that the recall of words on MMSE was also affected, a finding confirmed in our study. The correlation between STADP and GDS for discriminating validity was inverse $(r=-0.28 ; p=0.007)$, with the following stages: shortterm memory was $(r=-0.25 ; p=0.19)$, executive function and language on STADP $(r=-0.33 ; p=0.001)$, and episodic memory ( $r=-0.19 ; p=0.077)$, characterizing discriminating validity, a similar aspect to that found by Banhato and Nascimento ${ }^{14}$. A weak correlation $(r=-0.17 ; p=0.005)$ on the Center for Epidemiologic Studies - Depression Scale (CES-D) with the Symbols Search subtest (executive function test). However, executive function and language on STADP showed a significant correlation ( $r=0.33 ; p=0.001)$, a finding that demonstrates the possible interference of mood on executive functions and language in this test.

Content validity was initially achieved with the participation of specialists in task elaboration, using pieces from the Proverb Memory Game specifically designed for the elderly ${ }^{19,20}$. An earlier study showed a correlation between STADP with the total scores of the three standardized tests applied to sixty seniors - fourteen with initial $A D$ and forty-six without $A D$ - with MMSE $(r=0.64$; $p<0.001)$, semantic verbal fluency $(r=0.56 ; p<0.001)$ and clock drawing test $(r=0.50 ; p<0.016)^{21}$. In the present study these tests show significant correlations as do the others, and with GDS (inverse correlation). There was a stronger correlation with the CERAD word list $(r=0.61 ; p=0.000)$, data that agree with those observed by Bertolucci et al. ${ }^{28}$, who found sensitivity and specificity in the verbal memory tests. The functions evaluated in stage $B$ (executive functions and language) on STADP were significantly related to the standardized tests as follows: semantic ver- bal fluency ( $r=0.51 ; p=0.000)$, a test with good sensitivity $(75 \%)$ and specificity $(75 \%)^{28}$ and with DS, which obtained $r=0.42(p=0.000)$, confirming the literature ${ }^{7}$.

Acceptable internal consistency was found with respect to STADP, using Cronbach's Alpha coefficient (0.71). The correlations between the items of the three stages of the instrument under study were: short-term memory with executive functions and language was $(r=0.61)$; short-term memory with episodic memory ( $r=0.62)$; executive functions and language with episodic memory $(r=0.32)$. The correlations between these stages and the total score on STADP were stronger: $r=0.88(p=0.000)$ with short-term memory, $r=0.67(p=0.000)$ with executive functions and language, and $r=0.88(p=0.000)$ with episodic memory. The reaction time on STADP showed a significant correlation ( $r=0.28 ; p=0.006)$ with Neuropsi Figure reaction time and an inverse correlation with proverb recognition ( $r=-0.26 ; p=0.01$ ). The STADP memories also interfered in reaction time: episodic memory $(r=-0.36$; $\mathrm{p}=0.000)$, short-term memory $(r=-0.34 ; p=0.01)$ as well as in proverb recognition, requested after a mean of forty minutes: episodic memory $(r=0.37 ; p=0.000)$ and shortterm memory ( $r=0.28 ; p=0.007)$, pointing to better performance from those who better codified the information ${ }^{30}$. The same occurred with the total score on STADP ( $r=0.32$; $p=0.002$ ). Executive functions and language did not interfere in proverb recognition $(r=0.15 ; p=0.17)$, but did interfere in reaction time $(r=-0.30 ; p=0.005)$. There was also a good correlation between proverb recognition and the word list $(r=0.58 ; p=0.000)$.

There was a significant association between STADP screening and that of MMSE $(p=0.07)$ as well as between STADP and medical diagnosis ( $p=0.000$ ) (Table 4).

With respect to schooling, considering medical diagnosis, the cutoff point for 1-7 years of schooling was 6.49 , with sensibility of $80 \%$ and specificity of $77.8 \%$. Therefore, scores below 6.5 may predict the need for more thorough neuropsychological evaluation, shown on the ROC curve (Fig 1). In the $\geq 8$ years of schooling range the cutoff point found was 8.66 , sensitivity (84.6\%) and specificity ( $86.1 \%$ ), indicating a level below 8.67 on the STADP (Fig 2).

Participation in the retest, after three months, showed sample mortality of $8 \%$ and the reasons for non-partic- 


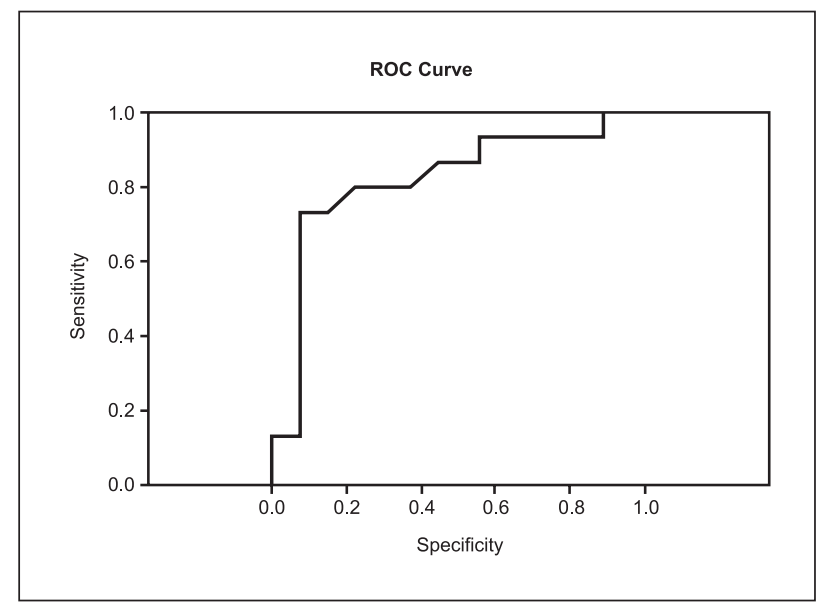

Fig 1. ROC curve of the elderly with 1-7 years of schooling, considering medical diagnosis.

ipation were: death, clinical comorbidity and loss of interest; however, it is believed that the offer of a memory workshop increased adherence. The consistency of interexaminer assessment was equal to $1(p=0.000)$.

\section{DISCUSSION}

The results strongly suggest that the Screening Test for Alzheimer's Disease with Proverbs (STADP) shows the psychometric properties of an instrument capable of identifying the initial alterations of $A D$, and may contribute, along with other instruments standardized in specialized centers.

The importance of short-term memory (stage A) on the STADP was marked, showing that learning is compromised in early $A D$, corroborating Campanha et al. ${ }^{16}$, who found significantly worse results in elderly with $A D$ in the recognition, interpretation and abstraction of popular proverbs, in addition to being a widely recommended instrument in the international literature about AD screening. The importance of episodic memory (stage $C$ ) was confirmed in $A D$ screening, agreeing with $C$ Charchat ${ }^{6}$ as to the importance of deficits in episodic memory for the transition from normality to the initial stages of AD. The internal consistency of the subtests show that they are adequate, ensuring the reliability of STADP without the need for new studies. There was no divergence between the examiners, further characterizing the reliability of the instrument. Attention was paid to the schooling variable and to the use of the corresponding cutoff points, showing greater sensitivity and specificity at higher schooling levels. It is hypothesized that the schooling levels found interfere in the abstract interpretation of proverbs (stage $B$ of STADP), although the difference is minimal in terms of sensitivity and specificity.

In regard to the importance of mood in the performance of the elderly on STADP, executive functions and

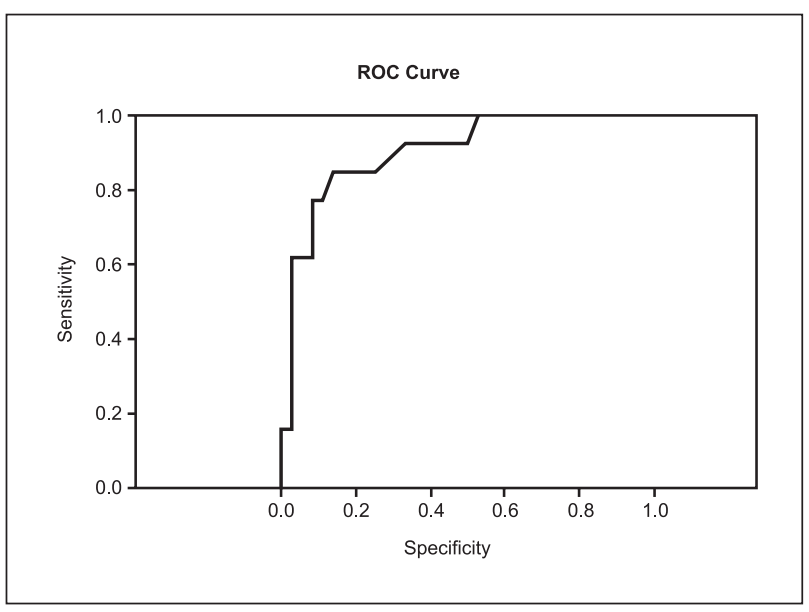

Fig 2. ROC curve of the elderly with $\geq 8$ years of schooling, considering medical diagnosis.

language showed a correlation $(r=-0.33 ; p=0.001)$, also observed by Argimon et al. ${ }^{4}$, and confirmed by Siviero ${ }^{17}$ as to the increase in number of errors in speech, in the interpretation of proverbs.

The greatest difficulty of the present study was in finding elderly individuals with $C D R=1$, a fact that restricted the sample. We observed a lack of health education in making the population aware of the importance of seeking treatment in the early phase of $A D$ and of professionals for screening at the specialized state institutions and even at private facilities. This finding justifies continued research in dementia screening and increased treatment by multidisciplinary teams.

ACKNOWLEDGEMENTS - To Dr. Gutemberg Guerra and Dr. Terce Liana for organizing the instrument and understanding of dementia, and to Dr. Lucas Gomes Andrade, an invaluable collaborator in elderly screening.

\section{REFERENCES}

1. Abreu ID de, Forlenza OV, Barros L de B. Demência de Alzheimer: correlação entre memória e autonomia. Rev Psiquiatr Clín 2005;32:131-136.

2. Botino CMC, Lopes MA. Prevalência de demência em diversas regiões do mundo. Arq Neuropsiquiatr 2002;60:1-15.

3. Nitrini R, Caramelli P, Bottino CMC, Damasceno BP, Brucki SMD, Anghinah R. Critérios diagnósticos e exames complementares: recomendações do Departamento de Neurologia Cognitiva e do Envelhecimento da Academia Brasileira de Neurologia. Arq Neuropsiquiatr 2005; 63:713-719.

4. Argimon II de L, Wendt GW, Souza G de S. Contribuições da avaliação neuropsicológica na investigação da doença de Alzheimer. RBCEH, Passo Fundo 2008;5:70-79.

5. Wajman JR. Avaliação neuropsicológica em idosos altamente intelectualizados. In: Ortiz KZ, Mendonça LIZ de, Foz A, Santos CB dos, Fuentes D, Azambuja DA de (Organizadores). Avaliação neuropsicológica: panorama interdisciplinar dos estudos na normatização e validação de instrumentos no Brasil. São Paulo: Editora Vetor 2008:104-112.

6. Charchat-Fichman. Heterogeneidade neuropsicológica no processo de envelhecimento: transição do normal aos estágios iniciais da doença de Alzheimer. São Paulo, 2003.

7. Hamdan AC, Bueno OFA. Relações entre controle executivo e memória 
episódica verbal no comprometimento cognitivo leve e na demência tipo Alzheimer. Estud Psicol Natal 2005;10:63-71.

8. Diniz CMC. Avaliação das funções executivas no idoso portador da doença de Alzheimer: correlação clínica e funcional. Dissertação de Mestrado. Escola Paulista de Medicina (Neurologia), Universidade Federal de São Paulo. São Paulo, 2007.

9. Pereira FS, Yassuda MS, Oliveira AM, Forlenza OV. Executive dysfunction correlates with impaired functional status in older adults with varying degrees of cognitive impairment. Cambridge University Press: International Psychogeriatrics, 2008;20:1104-1115.

10. Cruz M da N, Hamdan AC. O impacto da doença de Alzheimer no cuidador. Psicologia em Estudo, Maringá, 2008;13:223-229.

11. Siviero MO. Capacidade de abstração e o teste de provérbios. Dissertação de Mestrado. Escola Paulista de Medicina, Universidade Federal de São Paulo. São Paulo, 1997.

12. Ortiz KZ, Bertolucci PHF. Alterações de linguagem nas fases iniciais da doença de Alzheimer. Arq Neuropsiquiatr 2005;63:311-317.

13. Alchieri JC. Aspectos instrumentais e metodológicos da avaliação psicológica. In: Andrade VM, Santos FH, Bueno OFA (Eds). Neuropsicologia Hoje. Porto Alegre: Artes Médicas, 2004:13-36

14. Banhato EFC, Nascimento E. Funções executivas em idosos: um estudo utilizando subtestes da escala WAIS-III. PsicoUSF 2007;12:65-73.

15. Elmore CM, Gorhan DR. Measuring the impairment of the abstracting function with the Proverbs Test. J Clin Psychol 1957;13:263-266.

16. Campanha AC, Lira JO de, Ortiz ZZ, Bertolucci PH, Minett T. Uso de tarefas metalingüísticas para avaliação da linguagem e cognição em portadores da doença de Alzheimer e idosos saudáveis. Sociedade Brasileira de Fonoaudiologia. XVI Congresso Brasileiro de Fonoaudiologia. Departamento de Fonoaudiologia - UNIFESP. Campos do Jordão, 24-27/09/2008.

17. Fischer JS, Hannay HJ, Loring DW, Lezak MD. Observational methods, rating scales, and inventories. In: Lezak MD, Howieson DB, Loring DW (Eds). Neuropsychological assessment. New York: Oxford University Press, 2004:698-737.

18. Bertolucci PHF, Brucki SMD, Campacci SR, Juliano Y. O mini-exame do estado mental em uma população geral: impacto da escolaridade. Arq Neuropsiquiatr 1994;52:1-7.

19. Santos MTF, Carvalho TL, Bastos O, Sougey EB. Estudo piloto de desempenho menêmico com "Jogo de Memória de Provérbios" criado para idosos (abstract). Neurobiologia 2005;68:106-107.

20. Santos MTF, Guerra G, Menezes TL, Carvalho TL, Alchieri JC, Sougey EB. Preliminary data of validation for Mnemonic Instrument of Proverbs for Track of Alzheimer. (abstract). VI Encontro de Pesquisadores em DA e Desordens Relacionadas. Dementia Neuropsychol 2007;1:45.

21. Santos MTF, Guerra G, Menezes TL, Carvalho TL, Alchieri JC, Sougey EB. Preliminary data on a mnemonic instrument with proverbs for tracking Alzheimer's disease. Dementia Neuropsychol 2008;2:333-338.

22. Almeida OP. Mini Exame do Estado Mental e o diagnóstico de demência no Brasil. Arq Neuropsiquiatr 1998;56:605-612.

23. Ferrari J, Dalacorte RR. Uso da Escala de Depressão Geriátrica de Yesavage para avaliar a prevalência de depressão em idosos hospitalizados. Porto Alegre: Scientia Medica 2007;17:3-8.

24. Lourenço RA, Veras RP, Ribeiro PCC. Confiabilidade teste-reteste do Mini-Exame do Estado Mental em uma população idosa assistida em uma unidade ambulatorial de saúde. Rio de Janeiro. Rev Bras Geriatr Gerontol 2008;11(1). www.unati.uerj.br/tse/scielo.

25. Paradela EMP, Lourenço RL, Veras RP. Validação da Escala de Depressão Geriátrica em um ambulatório geral. São Paulo. Rev Saúde Pública 2005;39:918-923.

26. Souza P da LS, Falcão JT da R, Leal CC, Marino JG. Avaliação do desempenho cognitivo em idosos. Rio de Janeiro. Rev Bras Geriatr Gerontol 2007;10:29-38.

27. Filho JMC, Ramos LR. Epidemiologia do envelhecimento no Nordeste do Brasil: resultados de inquérito domiciliar. São Paulo, SP - Brasil (LRR). Rev Saúde Pública 1999;33:445-453.

28. Bertolucci PHF, Okamoto IH, Neto JT, Ramos LR, Brucki SMD. Desempenho da população brasileira na Bateria Neuropsicológica do Consortium to Establish a Registry for Alzheimer's Disease (CERAD). Órgão Oficial do Departamento e Instituto de Psiquiatria da Faculdade de Medicina da Universidade de São Paulo. Rev Psiquiatr Clín 1998;25:80-83.

29. Backman L, Jones S, Berger A-K, Laukka EJ. Cognitive Impairment in preclinical Alzheimer's disease: a meta-analysis. American Psychological Association 2005;19:520-531.

30. Degenszajn J, Caramelli P, Leonardo Caixeta L, Nitrini R. Encoding process in delayed recall impairment and rate of forgetting in Alzheimer's disease. Arq Neuropsiquiatr 2001;59:171-174. 